\title{
Ojcowie greccy o Maryi i Jej roli w historii zbawienia
}

Chociaż w kerygmacie Kościoła pierwotnego dominującą rolę odgrywało przesłanie chrystologiczne - głoszenie Chrystusa jako Syna Bożego, to jednak Maryja również się w nim pojawiała, a w tradycji chrześcijańskiej dość wcześnie ugruntowało się przekonanie o Jej Bożym macierzyństwie i istotnej roli w realizacji zbawczego planu Boga ${ }^{1}$. Opierało się ono przede wszystkim na wypowiedziach ewangelistów: Mateusza i Łukasza² ${ }^{2}$ którzy mówili o narodzinach Syna Bożego z Maryi Dziewicy ${ }^{3}$. Później do tych wypowiedzi zaczęto dołączać inne teksty, zwłaszcza zaczerpnięte ze Starego Testamentu, ale nie tylko, które - według starożytnych

1 Por. J.N.D. Kelly, Poczq̨tki doktryny chrześcijańskiej, tłum. J. Mrukówna, Warszawa 1988, s. 363.

2 Tylko ci dwaj ewangeliści wypowiadają się na ten temat. Święty Marek przemilcza temat dzieciństwa Jezusa, a swą Ewangelię rozpoczyna od opowiadania o działalności Jana Chrzciciela. W odniesieniu do Maryi ogranicza się do dwukrotnego zamieszczenia w swej Ewangelii wzmianki o Niej (por. Mk 3,31-35; 6,3), podkreślając, że jest Ona matką Jezusa. Święty Jan natomiast nie wykazuje szczególnego zainteresowania ukazaniem tego aspektu rzeczywistości ludzkiej Jezusa.

3 Ewangelista Mateusz wykazuje znajomość relacji o dzieciństwie Jezusa, lecz w swej narracji koncentruje się na osobie św. Józefa pochodzącego z rodu króla Dawida, podkreślając jego posłuszeństwo względem planów Bożych (por. Mt 1,20n; 2,13.20-21) i nadanie imienia Jezus Dziecku Maryi. 
egzegetów - wskazywały na wyjątkową rolę Maryi w dziele zbawienia. Ewangelia ukazuje zatem dwie podstawowe prawdy dotyczące Maryi: Jej Boże macierzyństwo oraz dziewictwo ${ }^{4}$. Nie dziwi więc, że były one punktem wyjścia mariologii patrystycznej ${ }^{5}$. W kolejnych częściach niniejszego opracowania postaramy się ukazać postępujący rozwój nauczania Ojców na temat Matki Bożej.

\section{Do I Soboru Nicejskiego (325)}

Z grona ojców apostolskich tylko Ignacy Antiocheński (ok. 30-ok. 107) wypowiada się na temat Maryi, której imię wymienia w swych listach cztery razy ${ }^{6}$. Biskup Antiochii jasno stwierdza, że według zbawczej ekonomii Boga Jezus począł się w łonie Maryi ${ }^{7}$, że został „zrodzony z Maryi i zrodzony

4 Por. W. Kania, Wstęp, w: Ojcowie Kościoła greccy i syryjscy. Teksty o Matce Bożej, red. tenże, t. 1, Niepokalanów 1981, s. 9; L. Padovese, Wprowadzenie do teologii patrystycznej, tłum. A. Baron, Kraków 1994, s. 106-109.

5 Literatura dotycząca mariologii patrystycznej jest przebogata. Ze względu na szczupłość i charakter przeglądowy niniejszego opracowania omówienie stanu badań zostanie pominięte. Literaturę na ten temat można odnaleźć w opracowaniach o charakterze słownikowym oraz obszernych monografiach. Zob. D. Kasprzak, Maryja w nauczaniu Kościoła epoki patrystycznej, w: Matka Pana w katechezie. Materiaty z XXXVI Sympozjum Katechetycznego Międzyzakonnego Wyższego Instytutu Katechetycznego w Krakowie (11 marca 2006 r.), red. A.E. Klich, t. 5, Kraków 2006, s. 137-167, spec. s. 137-138.

6 Por. H. Kraft, Clavis Patrum Apostolicorum. Catalogum vocum in libris Patrum qui dicuntur Apostolici non raro occurrentium, München 1963, s. 281, s.v. Mapía.

7 Por. Ignatius Antiochenus, Epistula ad Ephesios 18,2, Ignacy do Kościoła $w$ Efezie, tłum. A. Świderkówna, w: Pierwsi świadkowie. Pisma Ojców Apostolskich, Biblioteka Ojców Kościoła 10, Kraków 1998, s. 118: „Bóg nasz bowiem, Jezus Chrystus, począł się w łonie Maryi zgodnie z planem Bożym, z rodu Dawida i z Ducha Świętego. On to urodził się i został ochrzczony, aby oczyścić wodę przez swoją mękę". 
z Boga"8. Maryja jest zatem Matką Bożą. Warto zauważyć, że zestawiając w sposób dialektyczny człowieczeństwo i bóstwo w Chrystusie, Ignacy otwiera drogę do późniejszych stwierdzeń teologicznych Soboru Chalcedońskiego (451). Polemizując zaś z gnostyckimi tendencjami doketystycznymi ${ }^{9}$ podkreśla, że Maryja zrodziła prawdziwego człowieka ${ }^{10}$. Wyraża też przekonanie, że szatan nie zrozumiał „trzech głośnych tajemnic, które dokonały się w ciszy Boga: dziewictwa Maryi ani Jej macierzyństwa, podobnie jak i śmierci Pana"11. Na uwagę zasługuje fakt, że Igna-

8 Tamże 7,2, s. 115.

9 Genezy doketyzmu należy szukać zarówno w greckim dualizmie, jak i w myśli judaistycznej; por. J.G. Davies, The Origins of Docetism, „Studia Patristica” 6 (1962), s. 13-35; R. Goldstein, G.G. Stroumsa, The Greek and Jewish Origins of Docetism: A New Proposal, „Zeitschrift für antikes Christentum" 10 (2007), s. 423-441. Już św. Jan Apostoł przeciwstawiał się tendencjom doketystycznym (por. $1 \mathrm{~J}$ 4,1-3; $2 \mathrm{~J}$ 7), a w 2. poł. II w. powstała niezależna sekta doketów założona - według Klemensa Aleksandryjskiego (Stromata III 91,1; III 102,3) - przez Juliusza Kasjana, ucznia Walentyna; por. H. Masson, Stownik herezji w Kościele katolickim, tłum. B. Sęk, Katowice 1993, s. 111; B. Studer, Docetismo, w: Nuovo Dizionario Patristico e di Antichità Cristiane, ed. A. Di Berardino, t. 1, Genova-Milano 2006, kol. 1465-1466; Doketyzm, w: Nowy słownik wczesnochrześcijańskiego piśmiennictwa, red. M. Starowieyski, J.M. Szymusiak, Poznań 2018, s. 284.

10 Por. Ignatius Antiochenus, Epistula ad Trallianos 9,1, tłum. A. Świderkówna: Ignacy do Kościoła w Tralleis, w: Pierwsi świadkowie, s. 126: „Bądźcie więc głusi, kiedy wam mówią o czymś innym niż o Jezusie Chrystusie, z rodu Dawida, Synu Maryi, który naprawdę się narodził, który jadł i pił, naprawdę był prześladowany za Poncjusza Piłata, naprawdę został ukrzyżowany i umarł, a oglądały Go niebo i ziemia, i otchłań”. Na temat prawdziwego człowieczeństwa Chrystusa Ignacy wypowiada się jeszcze w innych swoich listach: por. tenże, Epistula ad Smyrneos 1-2, tłum. A. Świderkówna: Ignacy do Kościoła w Smyrnie, w: Pierwsi świadkowie, s. 136; tamże, 7,1-2, s. 137-138. Również późniejsi autorzy (Justyn, Ireneusz z Lyonu, Klemens Aleksandryjski) w kontekście walki z doketami podkreślali prawdziwość człowieczeństwa Jezusa.

11 Ignatius Antiochenus, Epistula ad Ephesios 19,1, tłum. A. Świderkówna, s. 118. 
cy, broniąc prawdziwości wcielenia, wiązał cudowne poczęcie i narodzenie Jezusa z Dziewicy Maryi z odkupieńczym planem Boga.

Również autorzy wczesnych apokryfów powstających na przełomie I i II wieku zainteresowani byli osobą Maryi. Podobnie jak autorzy Nowego Testamentu podkreślali oni cudowne poczęcie i narodzenie Jezusa z Maryi pochodzącej z rodu Dawida. Niezwykle interesujący jest przekaz autora Wniebowstapienia Izajasza - apokryfu datowanego na lata 80.-90. I wieku' ${ }^{12}$, który mówi o wierze pierwotnego Kościoła w dziewictwo Maryi zarówno przed poczęciem, jak i po urodzeniu Jezusa ${ }^{13}$ : „Potem [...] jej łono stało się, jak było przedtem, zanim poczęła"14, oraz o tym, że Maryja nie doświadczyła bólów porodowych ${ }^{15}$. Podobna myśl obecna jest w 19. Odzie Salomona - nieco późniejszym apokryfie z drugiej połowy II wieku. Autor tego pisma mówi o tym, że Maryja poczęła jako dziewica oraz że jako dziewica urodziła i stała się matką, nie doświadczając bólów rodzenia ${ }^{16}$. Jednak pod względem mariologicznym wyjątkowym apokryfem, niemal w całości poświęconym Maryi i podającym szereg szcze-

12 Apokryf ten składa się z dwóch części: Męczeństwa Izajasza (rozdz. 1-5) i Wizji Izajasza (rozdz. 6-11). Powstanie Wizji Izajasza datuje się na lata 80.-90. I wieku, a ostateczną redakcję tekstu na pierwsze dziesięciolecia II wieku. Por. E. Norelli, L'Ascensione di Isaia. Studi su un apocrifo al crocevia dei cristianesimi, Origini, Centro interdipartimentale di studi sull'ebraismo e sul cristianesimo antico, Università degli studi di Bologna, Nuova ser. 1, Bologna 1994, s. 66-67; R. Zarzeczny, [Wniebowstapienie Izajasza] Wstęp, w: Apokryfy Nowego Testamentu, t. 3: Listy i apokalipsy chrześcijańskie, red. M. Starowieyski, Kraków 2001, s. 136.

13 Por. Ascensio Isaiae (fragmentum aethiopicum) 11,5-14, Wniebowstapienie Izajasza, tekst etiopski, tłum. S. Kur, w: Apokryfy Nowego Testamentu, t. 3, s. 160-161.

14 Tamże, 11,9, s. 160.

15 Por. tamże, 11,14, s. 161.

16 Por. Odae Salomonis 19,6-9, Z Ód Salomona, Oda 19, tłum. M. Starowieyski, w: Apokryfy Nowego Testamentu, t. 1: Ewangelie apokryficzne, cz. 1: Fragmenty. Narodzenie i dzieciństwo Maryi i Jezusa, Kraków 2003, s. 155. 
gółów z Jej życia (narodzenie, dzieciństwo, ofiarowanie, zaślubiny z Józefem, dziewicze poczęcie Jezusa), jest Protoewangelia $J a k u b a^{17}$, której redakcję datuje się na drugą połowę II wieku. Jej przewodnią myślą dogmatyczną jest ukazanie Maryi jako dziewicy zarówno przed urodzeniem Jezusa, jak i w jego czasie oraz po nim. Dziewictwo Maryi podkreślone jest w ten sposób, że Józef - gdy został Jej opiekunem - według autora apokryfu był już starszym wdowcem mającym własne dzieci ${ }^{18}$, a poczęcie Jezusa nastąpiło podczas jego nieobecności w domu ${ }^{19}$. Narodzenie Jezusa z Maryi autor apokryfu ukazuje jako centrum dziejów zbawienia. Zawarte w dziele treści dogmatyczne mają też charakter antydoketystyczny: Maryja, chociaż jest dziewicą, jest prawdziwą matką Jezusa ${ }^{20}$, a sam Jezus ukazany jest jako prawdziwy człowiek (np. ssie pierś swej matki ${ }^{21}$; jest owijany w pieluszki ${ }^{22}$; jest obejmowany i tulony przez Salome ${ }^{23}$ ). Ważnym opowiadaniem, obecnie zaginionym, które najprawdopodobniej stało się źródłem wielu późniejszych tekstów noszących wspólny tytuł Zaśnięcie Najświętszej Maryi Panny, był apokryf zredagowany już w II lub III wieku opowiadający o śmierci, złożeniu w grobie i wzięciu do nieba Matki Bożej²

Chociaż przedstawione wyżej tezy mariologiczne były niezwykle doniosłe, to jednak potrzeba było sporo czasu, aby rozpowszechniły się w całym Kościele. Wprawdzie niektórzy z ojców Kościoła i pisarzy wczesnochrześcijańskich powtarzali je,

17 Por. W. Smereka, Najstarsza legenda o Matce Boskiej, „Ruch Biblijny i Liturgiczny" 16 (1963), s. 29-36.

18 Por. Protevangelium Iacobi 9,2, Protoewangelia Jakuba, tłum. M. Starowieyski, w: Apokryfy Nowego Testamentu, t. 1, cz. 1, s. 275.

19 Por. tamże, 9,3, s. 276.

20 Por. tamże, 19,3-20,1, s. 285.

${ }^{21}$ Por. tamże, 19,2, s. 284.

22 Por. tamże, 22,2, s. 288.

${ }^{23}$ Por. tamże, 20,2, s. 286.

24 Por. A. Strus, Legenda, tradycja i historia o zaśnięciu i wniebowzięciu NMP, „Ruch Biblijny i Liturgiczny” 37 (1984), s. 127-139 (spec. s. 129-132). 
jednak były to przypadki odosobnione. Przykładowo Arystydes z Aten (zm. 1. poł. II w.) podkreśla dziewictwo Maryi i nazywa Ją „świętą Dziewicą”, z której został zrodzony Jezus Chrystus Syn Boga Najwyższego „bez udziału nasienia i nieskażony, przyjął ciało i ukazał się ludziom, aby odstąpili od błędu politeizmu"25. Ukazuje zatem Maryję jako dziewicę-matkę, która dała Jezusowi prawdziwe ciało, natomiast bóstwo Chrystusa wynika z synostwa Bożego.

Święty Justyn (ok. 100 - między 163 a 167), podkreślając, że w osobie Jezusa Chrystusa spełniły się proroctwa mesjańskie zawarte w Starym Testamencie, przywołuje proroctwo Izajasza $(I z 7,14)$ i komentuje je w kluczu chrystologiczno-mariologicznym $^{26}$. Wyraźnie też mówi, że Boży Syn Jezus Chrystus narodził się z dziewicy Maryi, która pochodziła z rodu Dawida, Jakuba, Izaaka i Abrahama ${ }^{27}$. Najważniejszym osiągnięciem mariologicznym Justyna jest ukazanie Maryi jako przeciwieństwa Ewy ${ }^{28}$. On pierwszy dopełnił biblijną paralelę antytetyczną Adam Chrystus (por. Rz 5,14; 1Kor 15,21-22) paralelą Ewa - Maryja ${ }^{29}$, wprowadzając ją na stałe do teologii. Ewa i Maryja były dziewicami, Ewa przez nieposłuszeństwo Bogu stała się matką grzechu i śmierci wszystkich ludzi, a Maryja przez posłuszeństwo Bogu

${ }^{25}$ Aristides, Apologia 15,1, tłum. L. Misiarczyk, w: Pierwsi apologeci greccy, tłum. L. Misiarczyk, oprac. J. Naumowicz, Biblioteka Ojców Kościoła 24, Kraków 2004, s. 144.

26 Por. Justinus Martyr, Dialogus cum Tryphone Iudaeo 66-67, Św. Justyn, Dialog z Żydem Tryfonem, tłum. A. Lisiecki, Pisma Ojców Kościoła 4, Poznań 1926, s. 219-222.

27 Por. tamże, 23,3, s. 137; tamże, 43,1, s. 169; tamże, 100,3, s. 279; tamże, 113,4, s. 301; tamże, 120,1, s. 313, tłum. A. Lisiecki.

28 Szerzej na temat antytetyzmu teologicznego Ewa - Maryja w myśli pisarzy wczesnochrześcijańskich zob. S. Styś, De antithesis „Eva-Maria” eiusque relatione ad Protoevangelium apud Patres, "Collectanea Theologica" 23 (1952), s. 318-365.

29 Por. Justinus Martyr, Dialogus cum Tryphone Iudaeo 100,2-5, tłum. A. Lisiecki, s. 279-280. 
stała się matką Tego, który zniszczył dzieło Szatana i uwolnił ludzkość od śmierci wiecznej. Nietrudno zauważyć, że Maryja w nauczaniu wczesnochrześcijańskich apologetów greckich jest ukazywana jako dziewica-matka, z której narodził się Jezus prawdziwy Bóg i prawdziwy człowiek. Jednocześnie kontekst ich nauczania na temat Maryi jest wyraźnie chrystocentryczny.

Ireneusz z Lyonu (ok. 140-202) ${ }^{30}$, chociaż działający na Zachodzie, to jednak reprezentujący teologiczną tradycję azjatycką, był jedną z kluczowych postaci w historii mariologii. Biskup Lyonu wykorzystuje Pawłową koncepcję rekapitulacji, umieszczając ją w kontekście soteriologicznym, i ukazuje Maryję jako nową Ewę, a odnosząc się do wprowadzonej przez Justyna paraleli Ewa - Maryja, przedstawia obie niewiasty jako zamężne,

${ }^{30}$ Mariologia Ireneusza jest dość rozwinięta. Z ważniejszych prac zob. W. Scherer, Zur Mariologie des hl. Irenaus, „Zeitschrift für katholische Theologie" 47 (1923), s. 125-129; O. Bardenhewer, Zur Mariologie des hl. Irenäus, „Zeitschrift für katholische Theologie” 55 (1931), s. 600-604; J. Garçon, La Mariologie de Saint Irénée, Lyon 1932; G. Jouassard, Le „premier-né de la Vierge” chez saint Irénée et saint Hippolyte, „Revue des Sciences Religieuses” 12 (1932), s. 509-532; B. Przybylski, De mariologia sancti Irenaei Lugdunensis, Romae 1937; G. Jouassard, La théologie mariale de S. Irénée, w: L'Immaculée Conception. Actes du VIIe Congrès marial national de France, Lyon 1954, s. 265-276; J. Plagnieux, La doctrine mariale de saint Irénée, "Revue des Sciences Religieuses” 44 (1970), s. 179-189; A. Orbe, La "recirculatión” de la Virgen María en san Ireneo (Adv. Haer. III, 22, 4, 71), w: La mariologia nella catechesi dei Padri (Età prenicena). Convegno di studio e aggiornamento Facoltà di Lettere cristiane e classiche Pontificium Institutum Altioris Latinitatis, Roma, 18-19 marzo 1988, red. S. Felici, Roma 1989, s. 101-120; L. Gambero, Maria nel pensiero dei padri della Chiesa, Torino 1991, s. 45-54; K. Witko, Maryja w zbawczej „ekonomii” Ojca według „Adversus Haereses” Ireneusza z Lyonu, „Salvatoris Mater” 1 (1999), s. 179-184; E. Peretto, Percorsi mariologici nell'antica letteratura cristiana, Città del Vaticano 2001, s. 26-30; F. Rodrigo Polanco, La mariologia di sant'Ireneo, „Theotokos” 9 (2001), s. 359-400; B. Kochaniewicz, Antyteza Ewa-Maryja w „Adversus haereses” św. Ireneusza z Lyonu. Perspektywa apologetyczna, „Poznańskie Studia Teologiczne" 23 (2009), s. 89-102. 
jednak pozostające w stanie dziewiczym. Ewa, okazawszy nieposłuszeństwo, stała się „przyczyną śmierci” ${ }^{11}$ dla całego rodzaju ludzkiego, a Maryja, okazawszy posłuszeństwo, stała się „przyczyną zbawienia" ${ }^{2}$. Nieposłuszeństwo Ewy sprowadziło na całą ludzkość niewolę grzechu, a posłuszeństwo Maryi przywróciło ludziom stan pierwotnej wolności. Grzech i niewiara Ewy przeciwstawione są posłuszeństwu i wierze Maryi, „bowiem to, co dziewica Ewa zawiązała przez niewierność, to dziewica Maryja rozwiązała przez wiarę"33. Mówi też, że Jezus został „poczęty z Boga przez Ducha Świętego, zrodzony z Dziewicy Maryi, z tej, która była z rodu Dawida" ${ }^{34}$, oraz że przy rodzeniu Jezusa Maryja wolna była od bólów porodowych ${ }^{35}$. Nazywając Maryję „Orędowniczką Ewy” (advocata Evae) 36 i „Przyczyną zbawienia” (causa salutis $)^{37}$, zapoczątkował praktykę odnoszenia do Maryi innych tytułów honorowych, co w późniejszym okresie dało podstawy tworzenia litanii. Warto zauważyć, że nauczanie Ireneusza jest mocno osadzone w kontekście antyheretyckim (przede wszystkim antygnostyckim) i z tego też względu mówi on, że tylko wyznawcy prawdziwej wiary we właściwy sposób mogą zrozumieć miejsce i rolę Maryi w ekonomii zbawienia ${ }^{38}$.

${ }^{31}$ Irenaeus Lugdunensis, Adversus haereses 3,22,4, tłum. J. Brylowski: Św. Ireneusz z Lyonu, Adversus haereses, Pelplin 2018, s. 285.

32 Tamże, 3,22,4, s. 285-286.

33 Tamże, s. 286.

${ }^{34}$ Tenże, Demonstratio praedicationis apostolicae 40, Ireneusz z Lyonu, Wykład nauki apostolskiej, tłum. W. Myszor, Źródła Myśli Teologicznej 7, Kraków 1997, s. 58.

35 Tezę tę Ireneusz przedstawia, cytując i interpretując tekst Iz 66,7. Por. tamże, 54, s. 71: „W innym miejscu mówi także o Jego narodzeniu ten sam prorok: "Zanim ta, która ma rodzić urodzi i zanim nadejdą bóle porodu, wyjdzie (na świat) chłopiec» (Iz 66,7). Oznaczył przez to jego niezwykłe zrodzenie przez dziewicę"; por. tenże, Adversus haereses 3,21,6, tłum. J. Brylowski, s. 281.

36 Tenże, Adversus haereses 5,19,1, s. 472.

37 Tamże, 3,22,4, s. 285.

38 Tamże, 5,19,2, s. 472. 
Również dwaj wybitni teologowie reprezentujący aleksandryjskie środowisko teologiczne: Klemens Aleksandryjski (ok. 150-ok. 215) i Orygenes (ok. 185-ok. 254), pogłębili mariologię wczesnego Kościoła ${ }^{39}$. Klemens Aleksandryjski, podkreślając niezwykłe poczęcie Maryi, mówi, że Ona „poczęła z samej siebie, nie z kontaktu z mężczyzną"40. Mówi też o dziewictwie Maryi po urodzeniu Jezusa ${ }^{41}$ oraz o tym, że nie cierpiała bólów rodzenia ${ }^{42}$. Klemens dokonuje również interesującego zestawienia Maryi z Kościołem i mówi o nich jako o dwóch Dziewicach

39 Szerzej na temat mariologii Orygenesa zob. C. Vagaggini, Maria nelle opere di Origene, Orientalia Christiana Analecta 131, Roma 1942; $\mathrm{H}$. Crouzel, Introduction (I. La théologie marial d'Origène), w: Origène, Homélies sur S. Luc, Sources Chrétiennes 87, Paris 1962, s. 11-64; M. Starowieyski, Mariologia Orygenesa, w: Orygenes, Homilie o Ewangelii św. Łukasza, Pisma Starochrześcijańskich Pisarzy 36, Warszawa 1986, s. 5-29; F. Cocchini, Maria in Origene. Osservazioni storico-dottrinali, w: La mariologia nella catechesi dei Padri (Età prenicena), s. 133-140. Szczegółowa bibliografia: M. Starowieyski, Bibliografia (mariologia patrystyczna ogólna i wschodnia), „Częstochowskie Studia Teologiczne” 6 (1978), s. 99.

40 Clemens Alexandrinus, Stromata 7,94,3, Klemens Aleksandryjski, Kobierce zapisków filozoficznych dotyczących prawdziwej wiedzy, t. 2, tłum. J. Niemirska-Pliszczyńska, Warszawa 1994, s. 295. Podobną myśl wyraża Ireneusz; por. Irenaeus Lugdunensis, Adversus haereses 3,21,7, tłum. J. Brylowski, s. 282: „Józef niczego tu nie uczynił, a jedynie sama Maryja przez swoją zgodę i współdziałanie. [...], abyśmy pojęli, że z woli Bożej, a nie tylko po ludzku dokonało się Jego przyjście”.

41 Klemens nazywa Chrystusa „owocem Dziewicy” (Clemens Alexandrinus, Paedagogus 1,6,41, Klemens Aleksandryjski, Wychowawca, tłum. M. Szarmach, Toruń 2012, s. 43).

42 Por. tenże, Stromata 7,93,7, t. 2, s. 295: „Ale podobno szerokim masom, i to do dnia dzisiejszego, wydaje się, że Maryja była położnicą dlatego, że urodziła dziecko, choć położnicą nie była, ponieważ już po urodzeniu Dzieciątka, gdy była doglądana przez położną, jak powiadają niektórzy, znaleziono Ją dziewicą". Wydawca teksu informuje, że w tym miejscu Klemens powołuje się na Protoewangelię Jakuba 19. 
i dwóch Matkach ${ }^{43}$, gdyż obie są czyste jak dziewice i obie są kochające jak matki ${ }^{44}$.

Orygenes, odnosząc się w swych pismach do Maryi, nazywał ją „Matką Boga” i „Matką Zbawiciela”, podkreślając przy tym, że w swym łonie nosiła Syna Bożego. Akcentował, że takie wyróżnienie mogło dotyczyć jedynie świętej i czystej Dziewicy. Dlatego autor ten uznaje dziewictwo Maryi przez całe Jej życie ${ }^{45} \mathrm{i}$ twierdzi, że „bracia Jezusa” (por. Mt 13,55) nie zostali zrodzeni przez Maryję, lecz byli synami Józefa ${ }^{46}$. Orygenes odrzuca jednak tezę o tym, że Maryja nie cierpiała bólów rodzenia, gdyż - zgodnie $z$ Prawem - została poddana oczyszczeniu ${ }^{47}$. Interpretując proroctwo Symeona o mieczu, który przeniknie Jej duszę (por. Łk 2,35), twierdził, że Maryja przeżywała wątpliwości w wierze podczas męki swego Syna ${ }^{48}$. Warto też zauważyć, że starożytny historyk kościelny Sokrates (ok. 380-ok. 450) prze-

${ }^{43}$ W języku greckim rzeczownik „kościół” ( $\left.\square \kappa \kappa \lambda \eta \sigma i \alpha\right)$ jest rodzaju żeńskiego. Por. Słownik grecko-polski, t. 2, red. Z. Abramowiczówna, Warszawa 1960, s. 64-65.

${ }^{44}$ Por. Clemens Alexandrinus, Paedagogus 1,6,42, tłum. M. Szarmach, s. 43.

45 Por. Origenes, Commentarii in Mathaeum 10,17, Orygenes, Komentarz do Ewangelii według św. Mateusza, tłum. K. Augustyniak, Źródła Myśli Teologicznej 10, Kraków 1998, s. 62. Maryja jako trwająca w dziewictwie przez całe swe życie była - według Orygenesa - wzorem czystości dla kobiet, podobnie jak Jezus był wzorem czystości dla mężczyzn.

46 Por. tenże, Homiliae in Lucam 7,4, Orygenes, Homilie o Ewangelii św. Eukasza, tłum. S. Kalinkowski, Pisma Starochrześcijańskich Pisarzy 36, Warszawa 1986, s. 49: „Ci bowiem, których nazywano synami Józefa, nie urodzili się z Maryi, a i żaden tekst Pisma o tym nie wspomina!”.

47 Por. Origenes, Homiliae in Lucam 14,3, s. 68. Myśl ta pojawia się w De carne Christi 23 Tertuliana (ok. 150/160-po 220). Wydaje się zatem, że Orygenes mógł ją zaczerpnąć od tego pisarza.

48 Por. tamże, 17,7, s. 80: „a przecież i twoją [tj. Maryi] duszę przeniknie miecz niewiary, zostaniesz zraniona ostrzem niepewności, a myśli twoje będą cię nękać, gdy ujrzysz, że Ten, o którym usłyszałaś, że jest Synem Bożym, i wiedziałaś, że urodził się bez udziału męskiego nasienia, zostaje ukrzyżowany, umiera, podlega ludzkim cierpieniom". 
kazuje informację, z której wynika, iż Orygenes jako pierwszy

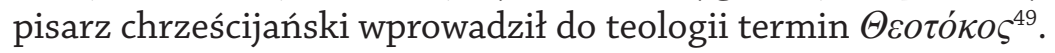

Niezwykle interesującym świadectwem czci, jaką była otaczana Maryja już od starożytności, jest przekaz Grzegorza z Nyssy (ok. 335-394/395) dotyczący Grzegorza Cudotwórcy (ok. 213-ok. 273). Biskup Nyssy w Żywocie Grzegorza Cudotwórcy informuje, że Grzegorz przed objęciem urzędu biskupa Neocezarei pewnej nocy modlił się, rozmyślając nad tajemnicami wiary. Wówczas ukazał mu się św. Jan Ewangelista wraz z Matką Bożą i pouczył go o istotnych prawdach wiary ${ }^{50}$. Jest to pierwsza historycznie poświadczona mariofania.

\section{Do II Soboru Konstantynopolskiego (553)}

Okres ten, naznaczony burzliwymi dyskusjami chrystologicznymi, przyniósł ostateczne potwierdzenie dwóch najstarszych „dogmatów” maryjnych: macierzyństwa Bożego i wiecznego dziewictwa Maryi. Po I Soborze Nicejskim zainteresowanie osobą Maryi znacznie wzrosło. Chrześcijańscy teologowie okresu ponicejskiego rozwijali mariologię $\mathrm{w}$ kontekście sporów $\mathrm{z}$ arianami, którzy m.in. zakwestionowali Bóstwo Chrystusa, a w kon-

${ }^{49}$ Por. Socrates, Historia ecclesiastica 7,32, Sokrates Scholastyk, Historia Kościoła, tłum. S.J. Kazikowski, Warszawa 1986, s. 543: „Orygenes w pierwszym tomie komentarzy do Listu Apostoła do Rzymian, objaśniając, w jakim sensie Maryja nazywana jest Bogarodzicielką, przeprowadził obszerne studium tego zagadnienia”. Por. M. Starowieyski, Tytut Theotokos w świadectwach przedefeskich, „Analecta Cracoviensia” 16 (1984), s. 409. Ksiądz Starowieyski podaje i komentuje kilka tekstów - niestety o wątpliwej autentyczności, w których Orygenes określa Maryję Theotokos (tamże, s. 418-421).

50 Por. Gregorius Nyssenus, De vita Gregorii Thaumaturgi, tłum. M. Starowieyski, w: M. Starowieyski, Najstarszy opis mariofanii, „Vox Patrum” 8 (1988) 15, s. 737-738, „Warszawskie Studia Teologiczne”, numer specjalny 2017, s. 308-317. 
sekwencji Boże macierzyństwo Maryi. Z tego też względu ortodoksyjni teologowie tamtego czasu, broniąc Bóstwa Chrystusa, bronili też Bożego macierzyństwa Maryi. W sposób najpełniejszy wyrażali je, określając Maryję jako Bogarodzicę. Za sprawą

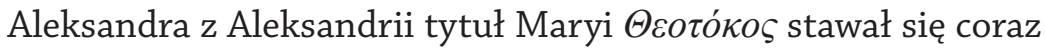
bardziej popularny ${ }^{51}$. Pisarze tego okresu coraz chętniej określali

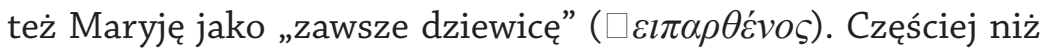
wcześniej odwoływali się też do paraleli antytetycznej Ewa Maryja $^{52}$, niekiedy wzbogacając ją o nowe niuanse teologiczne ${ }^{53}$.

Jednym $\mathrm{z}$ ważniejszych myślicieli tego okresu, którzy przypisywali Maryi istotne miejsce i rolę w ekonomii zbawczej, był Atanazy Aleksandryjski (ok. 295-373) ${ }^{54}$. Jako pierwszy myśliciel sformułował naukę o Bożym macierzyństwie Maryi, nazywając ją - za Orygenesem - $\Theta \varepsilon o \tau o ́ k o \varsigma^{55}$. Podkreślał, że dziewicze poczęcie i narodzenie Jezusa było znakiem Jego bóstwa, dlatego też dzie-

51 Por. Alexander Alexandrinus, Epistula ad Alexandrum Thessalonicensem 54, tłum. A. Caba, w: H. Pietras, Sobór Nicejski (325). Kontekst religijny i polityczny, dokumenty, komentarze, Kraków 2013, s. 91. List ten występuje pt. List do Aleksandra z Konstantynopola, jednak najprawdopodobniej został skierowany do Aleksandra z Tesalonik; por. H. Pietras, Sobór Nicejski (325), s. 65-67.

52 Por. np. Cyrillus Hierosolymitanus, Catechesis 12,15, Św. Cyryl Jerozolimski, Katechezy przedchrzcielne i mistagogiczne, tłum. W. Kania, Biblioteka Ojców Kościoła 14, Kraków 2000, s. 169; Gregorius Nyssenus, In canticum canticorum 13; Johannes Chrysostomus, Expositiones in Psalmos 24,7.

53 Por. Epiphanius Constantiensis, Panarion 78,18, gdzie Epifaniusz mówi, że to Maryja, bardziej niż Ewa, powinna nazywać się „matką wszystkich żyjących" (por. Rdz 3,20).

${ }^{54}$ Szerzej na temat mariologii tego autora zob. M. Starowieyski, $M a-$ riologia św. Atanazego Wielkiego, „Roczniki Teologiczno-Kanoniczne” 23 (1976) 4, s. 109-132, „Warszawskie Studia Teologiczne”, numer specjalny 2017, s. 318-346.

55 Szerzej na ten temat zob. J. Królikowski, „Theotokos” w teologii św. Atanazego. Przełom mariologiczny w I wieku i jego znaczenie, „Salvatoris Mater" 2 (2000), s. 56-73. 
wictwo Maryi było stałe - zawsze była dziewicą $(\square \varepsilon ı \pi \alpha \rho \theta \varepsilon ́ v o \varsigma)^{56}$. Nie dziwi więc, że o Maryi mówi jako o „dziewicy, nieskalanej, bez zmazy, nie znającej mężczyzny"57.

Jan Chryzostom (ok. 350-407) z kolei mówił jedynie o dziewiczym zrodzeniu Chrystusa przez Maryję ${ }^{58}$, które było wielkim cudem $^{59}$. Sporadyczność jego wypowiedzi na temat Maryi i brak pogłębionej refleksji na Jej temat może wynikać ze słabej świadomości Jej godności ${ }^{60} \mathrm{i}$ chrystologii przyjmowanej przez teologów reprezentujących tradycję antiocheńską.

Ojcowie kapadoccy: Bazyli Wielki (ok. 330-379), Grzegorz z Nyssy (ok. 335-394) i Grzegorz z Nazjanzu (ok. 330-390), odrzucili chrystologię szkoły antiocheńskiej, kryjącej w sobie supozycje, jakoby Maryja zrodziła jedynie człowieka - Jezusa, i nazywali Ją Bogarodzicą, a Grzegorz z Nazjanzu w Liście do

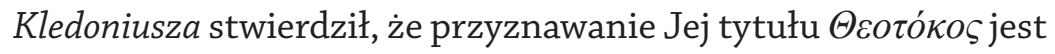
kryterium ortodoksji: „Kto świętej Maryi nie uważa za Bogarodzicę, jest poza boskością" ${ }^{1}$.

Warto też zauważyć, że pisarze greccy tego okresu - najprawdopodobniej idąc za Orygenesem - dalecy byli od przyznawania Maryi duchowej i moralnej doskonałości i wyrażali przekonanie, że podlegała ona ludzkim słabościom. Przykładowo Bazyli

56 Por. np. Athanasius Alexandrinus, Orationes contra Arianos 2,70, Atanazy Wielki, Mowy przeciw arianom I-III, tłum. P.M. Szewczyk, Źródła Myśli Teologicznej 67, Kraków 2013, s. 156.

57 Tenże, Oratio de incarnatione Verbi 8,3, Atanazy z Aleksandrii, O wcieleniu Słowa, tłum. M. Wojciechowski, Pisma Starochrześcijańskich Pisarzy 61, Warszawa 1998, s. 29.

58 Por. Johannes Chrysostomus, In Matthaeum homiliae 5,2, Św. Jan Chryzostom, Homilie na Ewangelię według św. Mateusza, tłum. J. Krystyniacki, oprac. A. Baron, t. 1, Źródła Myśli Teologicznej 18, Kraków 2000, s. 69-71.

59 Por. tamże, 25,3, s. 312.

60 Por. C. Baur, Johannes Chrysostomus und seine Zeit, t. 1: Antiochien, München 1929, s. 298.

${ }^{61}$ Gregorius Nazianzenus, Epistula 101, Św. Grzegorz z Nazjanzu, Listy, tłum. J. Stahr, Pisma Ojców Kościoła 15, Poznań 1933, s. 133. 
Wielki, nawiązując do proroctwa Symeona (por. Łk 2,35), wkłada w jego usta słowa, które jednoznacznie sugerują, że Maryja stojąca pod krzyżem swego Syna doznała zwątpienia w wierze ${ }^{62}$. Natomiast Jan Chryzostom, analizując perykopę opowiadającą o weselu w Kanie Galilejskiej (por. J 2,1-11), mówi, że zachęta Maryi, aby Jezus zainterweniował i pomógł nowożeńcom, była przejawem Jej zbytniej zapobiegliwości i chęci okazania władzy nad swym synem, za co słusznie została skarcona ${ }^{63}$.

Nowym impulsem do pogłębienia nauki na temat Maryi było błędne nauczanie Nestoriusza (ok. 381-ok. 451), który występował przeciw nazywaniu Jej Bogarodzicą. Nauczanie biskupa Konstantynopola wynikało z przyjmowanej przez niego chrystologii szkoły antiocheńskiej, w której precyzyjnie odróżniano właściwości boskie Chrystusa od ludzkich. Maryja zatem - w świetle ta-

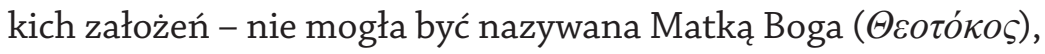

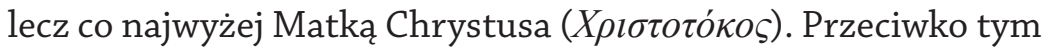
poglądom wystąpił Cyryl Aleksandryjski (ok. 375-444), który przedstawił naukę o dwóch naturach Chrystusa złączonych w Boskiej Osobie Słowa. Zjednoczenie obu natur nazwał unią hipostatyczną. Przez wcielenie obie natury nie uległy zmieszaniu ani nie stworzyły nowej jakości. Chrystus zatem posiada całko-

62 Por. Basilius Caesariensis, Epistula 260,9, Św. Bazyli Wielki, Listy, tłum. W. Krzyżaniak, Warszawa 1972, s. 321-322: „Symeon mógł co do Maryi wypowiedzieć proroctwo: «Stojąc pod krzyżem, patrząc na to, co się dzieje, i słysząc słowa, po zwiastowaniu Gabriela, po tajemnym poznaniu Bożego poczęcia, po świadectwie rozlicznych cudów - i w twojej duszy doznasz pewnego zachwiania»".

63 Por. Johannes Chrysostomus, In Matthaeum homiliae 44,2, tłum. A. Baron: Św. Jan Chryzostom, Homilie na Ewangelię według św. Mateusza, oprac. A. Baron, t. 2, Źródła Myśli Teologicznej 23, Kraków 2001, s. 45: „To samo uczynił [Jezus] na weselu [w Kanie Galilejskiej], gdzie zganił /Maryję/ za Jej niewczesne żądanie, a jednak Jej nie odmówił. Przez tamto uleczył Jej słabość, /w Kanie/ natomiast okazał swoją życzliwość względem Matki, w podobny sposób lecząc chorobę próżności i oddając Jej należytą cześć, chociaż żądanie wysunęła w niestosownej chwili”. 
witą i doskonałą naturę ludzką oraz całkowitą i pełną naturę boską. $Z$ racji unii hipostatycznej można odnosić do Chrystusa, Boga-Człowieka, przymioty obu Jego natur. Jest to tzw. współorzekanie przymiotów (communicatio idiomatum). Konsekwencją przyjęcia takiej chrystologii było nazywanie Maryi Bogarodzicą. W obliczu narastającego konfliktu cesarz Teodozjusz II (401-450) zdecydował się na zwołanie Soboru Efeskiego (431) ${ }^{64}$, na którym naukę Nestoriusza definitywnie odrzucono ${ }^{65}$, a on sam został potępiony ${ }^{66}$. Chociaż ojcowie soborowi nie wypracowali żadnej definicji dogmatycznej, to jednak przez głosowanie wyrazili aprobatę treści zawartych w Drugim liście Cyryla do Nestoriusza ${ }^{67}$, w tym dla określenia Maryi mianem Bogarodzicy

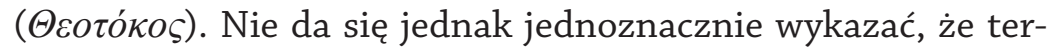

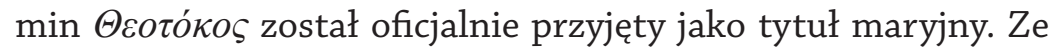
względu na różnice stanowisk przedstawicieli chrystologii aleksandryjskiej i antiocheńskiej w 433 roku doszło do tzw. synodu zgody, na którym wypracowano wspólną formułę wiary potwierdzającą jedność dwóch natur w Chrystusie, w której Maryja na-

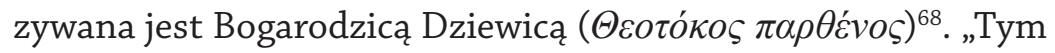
samym przyjęto założenia, które z czasem potwierdziła Tradycja Kościoła, że na Soborze Efeskim zostało ustalone i zatwierdzone pierwsze obowiązujące wszystkich chrześcijan nauczanie

64 Z okazji 1550. rocznicy Soboru Efeskiego odbyło się w Niepokalanowie „Sympozjum Efeskie”, z którego materiały zostały opublikowane w: Maryja w tajemnicy Chrystusa, red. S.C. Napiórkowski, S. Longosz, Biblioteka Mariologiczna 2, Niepokalanów 1997.

65 Por. K. Schatz, Sobory Powszechne. Punkty zwrotne w historii Kościoła, tłum. J. Zakrzewski, Kraków 2001, s. 49-51.

66 Por. M. Starowieyski, Sobory Kościoła niepodzielonego, cz. 1: Dzieje, Tarnów 1994, s. 56.

67 Por. tamże.

68 Por. Formula unionis, tłum. A. Baron, H. Pietras, T. Wnętrzak, w: Dokumenty soborów powszechnych, t. 1, Źródła Myśli Teologicznej 24, Kraków 2001, s. 177-179. 
nazywające Świętą Dziewicę ( $\tau \square v \square$ yíav $\pi \alpha \rho \theta \varepsilon ́ v o v)$ Bogarodzicą

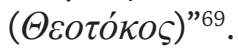

Proklus z Konstantynopola (zm. 446) w Kazaniu ku czci Najświętszej Dziewicy wychwalał dziewictwo i boskie macierzyństwo Maryi $^{70}$.

Z powyższego jasno wynika, że debaty chrystologiczne toczące się w V wieku wyznaczyły szczyt rozwoju mariologii patrystycznej. Trzeba też mieć świadomość, że ich celem nie było pogłębienie refleksji teologicznej na temat Maryi, lecz wyjaśnienie jedności bóstwa i człowieczeństwa wcielonego Słowa. Interesujące jest, że teologowie zgodnie przyjęli, że wyjaśnienie tego problemu leży w uznaniu Maryi za prawdziwą Bogarodzicę. Ta konkluzja uwydatniła Jej rolę w ekonomii zbawczej i niewątpliwie przyczyniła się do podniesienia Jej godności.

\section{Do końca epoki patrystycznej}

W tym czasie do stale potwierdzanych dwóch najstarszych „dogmatów" maryjnych dołączono dwa nowe wątki teologiczne, związane z początkiem i końcem życia Maryi, czyli z Jej niepokalanym poczęciem i chwalebnym wniebowzięciem po śmierci. Pustkę grobowca Maryi w Jerozolimie i brak Jej relikwii interpretowano jako świadectwo Jej cielesnego wzięcia do nieba. Teologowie tacy jak Theoteknos z Livias (zm. ok. 600) i Modest z Jerozolimy (ok. 537-ok. 634) starali się pogłębić tajemnicę wzięcia Maryi do nieba, odnosząc ją do już istniejących dogmatów maryjnych (w swych rozważaniach na ten temat woleli ter-

69 D. Kasprzak, Maryja w nauczaniu Kościoła epoki patrystycznej, s. 157$-158$.

70 Por. Proclus Constantinopolitanus, Homilia De laudibus s. Mariae, Św. Proklus, Kazaniu u czci Najświętszej Dziewicy, tłum. W. Kania, w: Starożytne teksty chrześcijańskie. Kazania i homilie na święta pańskie i maryjne, red. L. Gładyszewski, Lublin 1976, s. 75-78. 


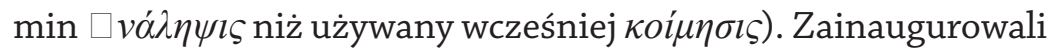
aksjomat assumpta quia immaculata, jednak ojcowie wschodni nigdy nie zdołali tak naprawdę wyrazić, czym było niepokalane poczęcie, określone w późniejszym dogmacie o niepokalanym poczęciu jako praeservatio - zachowanie od grzechu. Przywiązywali oni jednak ogromną wagę do wzięcia Maryi do nieba i Jej pośrednictwa. Czcili Maryję jako królową. W swoich kazaniach na temat wniebowzięcia German z Konstantynopola (ok. 634-733), Andrzej z Krety (ok. 650-ok. 740) i Jan z Damaszku (ok. 675-ok. 749) pogłębili wiarę w cielesne wzięcie Maryi do nieba i jej niebiańskie pośrednictwo.

Do rozkwitu mariologii i pobożności maryjnej przyczynił się również bardzo intensywnie rozwijający się ruch ascetyczny, w którym niezwykle wysoko ceniono dziewictwo jako pewien ideał i drogę do osiągnięcia zjednoczenia z Bogiem. Dziewictwo Maryi było podkreślane już przez najwcześniejszych pisarzy kościelnych i zawsze było łączone z Chrystusem. Zatem Maryja-Dziewica spełniała kryteria pewnego wzorca moralnego, który zaczęto przyjmować w gronie ascetów ${ }^{71}$, i dość szybko stała się prawdziwą przewodniczką mnichów, ascetów i dziewic oraz ludzi świeckich pragnących bardziej poświęcić się Bogu ${ }^{72}$. Przykładowo Atanazy Aleksandryjski ukazywał Maryję jako idealny wzór dla dziewic ${ }^{73}$.

$\mathrm{Na}$ zakończenie warto wspomnieć o starożytnym kulcie maryjnym. Najstarszym tego świadectwem jest znana modlitwa Sub Tuum praesidium, która najprawdopodobniej została zredagowana w środowisku egipskim w połowie III wieku ${ }^{74}$. W tej antyfonie

71 Por. S. De Fiores, Vergine, w: Nuovo Dizionario di Mariologia, ed. S. De Fiores, S. Meo, Torino 1985, s. 1458.

72 Por. B. Forte, Maryja, ikona Tajemnicy. Zarys mariologii symboliczno-narracyjnej, tłum. B. Widła, Warszawa 1999, s. 119.

73 Por. Athanasius Alexandrinus, De virginitate 3.

74 Por. G. Giamberardini, Il culto mariano in Egitto nei primi secoli, Cairo 1967, s. 103. 
Maryja ukazana jest jako orędowniczka oraz określana terminem Bogarodzica - $\Theta \varepsilon o \tau o ́ \kappa o \varsigma^{75}$. Z informacji tych wynika, że już dość wcześnie rozwijała się pobożność maryjna, a w pobożności ludowej w IV wieku kierowanie modlitw do Maryi wydaje się czymś zupełnie naturalnym. O takiej modlitwie wspomina Grzegorz z Nazjanzu, który opowiada o pewnej dziewicy, która prosiła Matkę Bożą, aby pomogła jej w niebezpieczeństwie ${ }^{76}$.

W IV wieku pojawiły się liturgiczne obchody ku czci Najświętszej Maryi Panny. Najpierw w Jerozolimie zaczęto obchodzić święto Oczyszczenia Maryi wraz z Ofiarowaniem Jezusa w świątyni, a w Antiochii czczono śmierć świętej Dziewicy. W V wieku pojawiło się czysto maryjne święto Zwiastowania, które dołączono do cyklu świąt związanych z Bożym Narodzeniem. 15 sierpnia zaczęto obchodzić „Zaśnięcie Maryi”, a 9 grudnia „Poczęcie Maryi", które w VIII wieku nabrało charakteru hołdu składanego Maryi wolnej od grzechu pierworodnego. W VIII wieku obchodzono uroczystość Ofiarowania Maryi w świątyni. Warto też zaznaczyć, że już przed Soborem Efeskim Bogarodzicy dedykowano wiele kościołów.

W podsumowaniu należy zauważyć, że refleksja mariologiczna greckich ojców Kościoła nie była systematyczna, lecz stanowiła pewnego rodzaju mozaikę wybranych elementów dogmatycznych, egzegetycznych i moralnych związanych z osobą Maryi. Zasadniczo rodziła się w kontekście innych ważnych tematów teologicznych, zwłaszcza chrystologicznych, związanych z obroną ortodoksji przed różnymi herezjami oraz nauczaniem wiary. Chociaż pierwsi greccy pisarze kościelni doby starożytnej nie

75 Por. tenże, Il „Sub Tuum praesidium” e il titolo „Theotokos” nella tradizione egiziana, „Marianum” 31 (1969), s. 324-362; M. Starowieyski, Tytut Theotokos w świadectwach przedefeskich, s. 421-423.

76 Por. Gregorius Nazianzenus, Oratio 24,11, w: Św. Grzegorz z Nazjanzu, Mowy wybrane, tłum. zbiorowe, Warszawa 1967, s. 266-267. 
mieli wypracowanych odpowiednich terminów teologicznych dla wyrażenia tajemnic chrystologicznych, godności i roli Matki Bożej, to jednak od początku poprawnie interpretowali Pismo Święte i Tradycję Kościoła, torując drogę późniejszemu rozwojowi mariologii. W początkowym okresie zajmowali się przede wszystkim wykazywaniem Bożego macierzyństwa i wiecznego dziewictwa Maryi, w późniejszym zaś do wspomnianych zagadnień dołączyli dwa nowe wątki teologiczne związane z niepokalanym poczęciem i chwalebnym wniebowzięciem Matki Bożej.

\section{I padri greci sulla Vergine Maria e sul suo ruolo nella storia della salvezza}

La riflessione mariologica dei Padri della Chiesa Greca non era sistematica, ma rapressentava una specie di mosaico di elementi selezionati dogmatici, esegetici e morali legati alla persona di Maria. Essa nasceva fondamentalmente nell'ambito di altri importanti argomenti teologici, soprattutto cristologici, legati alla difesa dell'ortodossia dalle varie eresie ed all'insegnamento della fede. Sebbene i primi scrittori ecclesiastici greci nell'antichità non avessero elaborato dei termini teologici appropriati per esprimere i misteri Cristologici nonché la dignità ed il ruolo della Madre di Dio, tuttavia, sin dall'inizio interpretarono correttamente le Sacre Scritture e la Tradizione della Chiesa, spianando la via per il successivo sviluppo della mariologia. Nel periodo iniziale essi si occuparono principalmente della dimostrazione della Divina maternità nonché dell'perpetua verginità di Maria, ed in seguito aggiunsero a questi argomenti due nuovi temi teologici relativi all'Immacolata Concezione della Beata Vergine Maria ed alla gloriosa Assunzione della Madre di Dio. 